\title{
HIDDEN ON THE SHORE FOR HALF A CENTURY: ACTUAL DISTRIBUTION OF SCHOENOPLECTUS PUNGENS (CYPERACEAE) IN HUNGARY
}

\author{
Mátyás WolF ${ }^{1}$, Dávid SCHMIDT ${ }^{2}$, Róbert VIDÉKI ${ }^{3}$, Viktor TiborCZ ${ }^{4} \&$ \\ Attila MesterházY ${ }^{5}$ \\ ${ }^{1}$ Bajcsy-Zsilinszky Endre u. 54, H-8999 Zalalövö, Hungary; matyas.wf@gmail.com \\ ${ }^{2,4}$ Institute of Botany and Nature Conservation, University of Sopron, \\ H-9400 Sopron, Bajcsy-Zsilinszky u. 4, Hungary; \\ schmidt.david@uni-sopron.hu,tibvik@freemail.hu \\ ${ }^{3}$ Doronicum Kft, H-9794 Felsöcsatár, Petöfi Sándor u. 13, Hungary; rvideki@gmail.com \\ ${ }^{5}$ Hortobágy National Park Directorate, H-4026 Debrecen, Sumen u. 2, Hungary; \\ amesterhazy@gmail.com
}

Wolf, M., Schmidt, D., Vidéki, R., Tiborcz, V. \& Mesterházy, A. (2019): Hidden on the shore for half a century: actual distribution of Schoenoplectus pungens (Cyperaceae) in Hungary. - Studia bot. hung. 50(1): 107-120.

\begin{abstract}
Schoenoplectus pungens is a little-known member of the Hungarian flora, where it is considered very rare. In recent years it was found in several locations, mostly in disturbed, anthropogenic habitats along the southern coast of Lake Balaton. Its historical and actual distribution in Hungary are presented, based on the revision of the literature data and the relevant Hungarian herbaria. Despite the extensive habitat destruction in its former locations, it has survived in manmade habitats in settlements, e.g. beaches, ditches, and mowed lawns, where mostly small, scarcely flowering individuals develop. These populations can be very inconspicuous and could therefore be passed unnoticed during previous field studies. We also emphasize that the flora of the southern coast of Lake Balaton needs additional study, and that in the anthropogenic habitats of the settlements further populations of $S$. pungens and other rare or declining species may be found.
\end{abstract}

Key words: anthropogenic habitats, distribution, Lake Balaton, Schoenoplectus pungens

\section{INTRODUCTION}

Schoenoplectus pungens (Vahl) Palla (Cyperaceae) is a perennial herb, which grows in various habitats including brackish and coastal shores, banks of lakes and ponds, marshes and ditches. It has a very widespread distribution and can be found throughout North America, in Central and southern America, southern Russia, Central Asia, Japan, Australia, and New Zealand (BALl et al. 2002, GovaERTs et al. 2007). In Europe it is also quite widespread but nowhere frequent in its range (Fig. 1). In western Europe there are sporadic occurrences along the Atlantic coast extending from the Netherlands southwards to Portugal 
(DeFilipps 1980, LuCEÑo \& Jiménez Mejías 2007). On its only site in Great Britain it disappeared in 1972 and was reintroduced later (PRESTON et al. 2002, STACE 2010). It was considered extinct in Belgium, but was rediscovered later (VAN LANDUYT et al. 2006). The species is regarded as endangered in Spain (BAÑARES et al. 2004), and there are scarce recent observations in Portugal. In the Mediterranean region scattered occurrences are known in southeastern France (PIRES \& PAVON 2018) and in northern Italy reaching the Adriatic coast to the east (PignotTi 2003).

In Central Europe $S$. pungens is very sporadically distributed with only a few actual localities. It is critically endangered in Switzerland and Austria (BORNAND et al. 2016, FisCHER et al. 2008), as well as in the North German Plain and on the northern coasts of Germany (HAEUPLER \& MUER 2007). In Austria, besides its hitherto known localities in Seewinkel, there is a very recent occurrence in Wien, which is considered adventive (GILLI \& NIKLFELD 2018). In Poland it is classified as extinct (KAŹmierCzAKowa et al. 2016). The only record from the Czech Republic is apparently erroneous (DANIHELKA et al. 2012). S. pungens was recently discovered on a lake margin in Western Polesia in northwestern Ukraine, as a new species for the flora of Eastern Europe (DANYLYK \& HONCHARENKO 2009).

In Hungary Soó (1973) summarized the distribution of S. pungens, with complements based mostly on processed herbaria. Besides the known localities at Lake Balaton he mentioned occurrences at the riversides of the Danube (Dunaföldvár) and the Dráva (Zákány), at Lake Fertő, as well as an extinct population in Budapest. Most of the former records could not be confirmed during

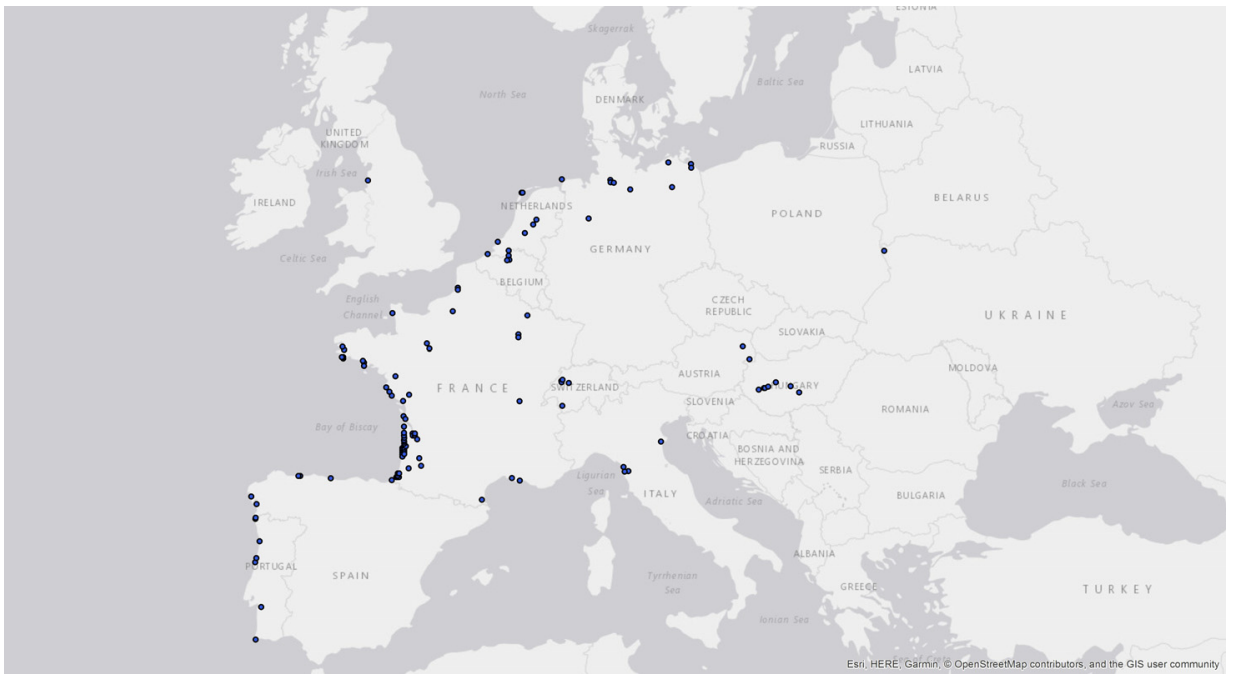

Fig. 1. European distribution of Schoenoplectus pungens (only data after 1950 are shown). 
recent systematical field work (BARTHA et al. 2015). At present, this relatively little-known species is considered very rare (KIRÁLY 2009) with only very few known actual localities. It is included in the red list of Hungarian vascular plants (KIRÁLY 2007) as 'vulnerable' but, despite its rarity, not in the list of protected plants of Hungary. The aim of this paper is to present the historical and actual distribution of $S$. pungens in Hungary, based on literature data, herbarium records, and several newly discovered or rediscovered populations. The potential causes of its decline are also discussed.

\section{MATERIALS AND METHODS}

The field studies were conducted between 2013 and 2018. The research also included the revision of the following Hungarian herbaria: Hungarian Natural History Museum, Budapest (BP); University of Debrecen, Debrecen (DE); Savaria Museum, Szombathely (SAMU); Balaton Museum, Keszthely (KBM); University of Pannonia, Keszthely (GK). Nomenclature of vascular plants follows KirÁLY (2009).

The CEU grid numbers for the Hungarian locations are given in brackets according to the Central European Mapping Scheme (NikLfeld 1971). For the assessment of the actual distribution of the studied species in Europe and the construction of the European distribution map the following websites were used (in addition to the literature cited in the text): https://waarneming.nl (the Netherlands), https://waarnemingen.be (Belgium), http://siflore.fcbn.fr (France), www.floraweb.de (Germany), www.infoflora.ch (Switzerland), and https://flora-on.pt (Portugal).

ArcMap 10.4.1. was used to produce the European distribution map. The photographs of the fruits were taken by using a Canon PowerShot A2100 IS on macro setting through a microscope. Digital images were adjusted in Photoshop to improve clarity.

\section{The studied species}

Based on Ball et al. (2002), Pignotti (2003), and Fischer et al. (2008) Schoenoplectus pungens is a rhizomatous perennial with erect, sharply trigonous stems, up to $100 \mathrm{~cm}$ tall. It has basal leaves with leaf sheaths up to $10 \mathrm{~cm}$, the uppermost 2(-3) with a V-shaped, linear, 3-40 cm long blade. The inflorescence is capitate with 1-6 sessile, 5-10 mm long spikelets. The lower bract is stem-like, erect, trigonous, 3-12 cm long, the other bracts are glumaceous. The glumes are reddishbrown, incised, with a $0.5-1 \mathrm{~mm}$ long mucro and acute, ciliate lateral lobes. The perianth bristles are absent or 1-2, rudimentary, much shorter than the nutlet. 
In Europe only the nominate var. pungens occurs, which is characterized by bifid styles and lenticular achenes, whereas the species is highly variable in North America with three recognized varieties, and belongs to the problematic "Scirpus americanus complex". The European plants are usually easily distinguished from related species by the presence of rhizomes, the trigonous stem, the stem-like bract and the apparently lateral inflorescence with only sessile spikelets. Nevertheless, poorly developed individuals of $S$. triqueter without pedunculate spikelets can be mistaken for $S$. pungens. The identification key in the recent Hungarian Flora (KIRÁLY 2009) focuses on the presence or absence of pedunculate spikelets and on the length of the leaf blade, but these characteristics are not always reliable.

Other important characters that can help distinguish these two species are that $S$. triqueter has glumes with obtuse lateral lobes and 4-6 perianth bristles about equalling the nutlet in length, while $S$. pungens has glumes with acute lateral lobes and 0-2 perianth bristles which are much shorter than the nutlet (Fig. 2).

A
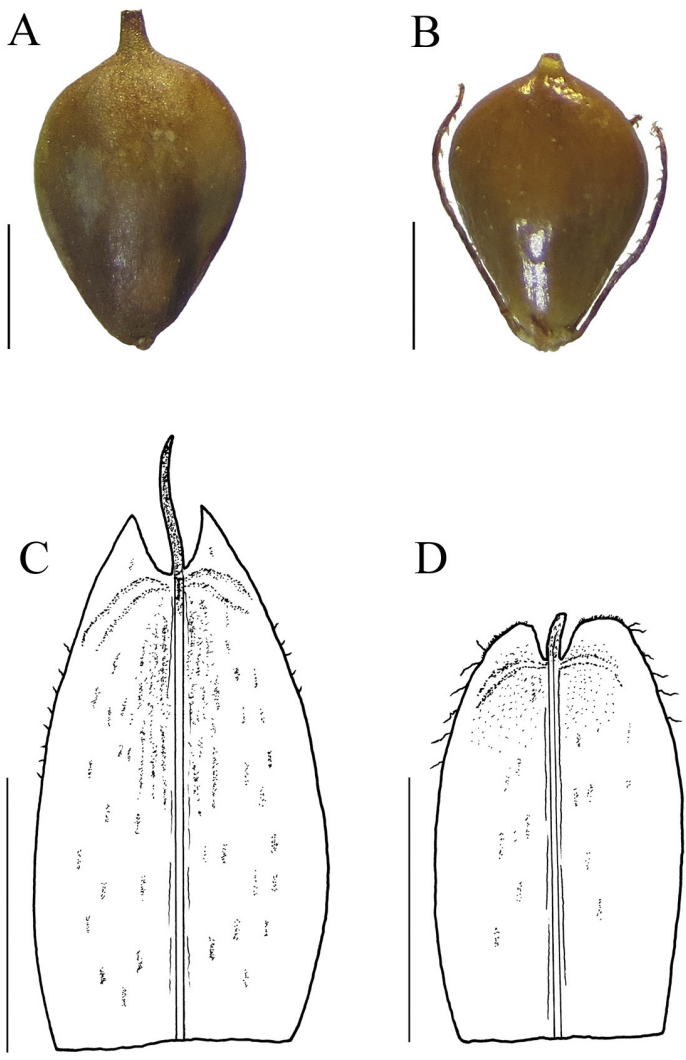

Fig. 2. A $=$ Nut of $S$. pungens. $\mathrm{B}=$ Nut of $S$. triqueter. $\mathrm{C}=$ Glume of $S$. pungens. $\mathrm{D}=$ Glume of $S$. triqueter. Scale bars represent $1 \mathrm{~mm}$ for nuts and $2 \mathrm{~mm}$ for glumes. 
The depiction of the perianth bristles of $S$. pungens in the second volume of the Hungarian Flora (KIRÁLY et al. 2011) is unfortunately not typical for the species. Members of the Bolboschoenus maritimus group may superficially resemble S. pungens, but they usually have leaves on the stem up to the middle, an obviously terminal inflorescence with more than one, leaf-like bracts, more than $1 \mathrm{~cm}$ long spikelets and incised glumes with a 1-3 mm long mucro.

\section{RESULTS}

We present our data per region, presenting data from literature and herbarium revision, as well as a brief description of the recently found locations. The majority of the data originates from the Great Hungarian Plain (Danube valley and DanubeTisza Interfluve) and the Transdanubian Hills (Balaton coast, Tapolca basin, and Dráva valley). One herbarium record originates from the Small Hungarian Plain.

Herbarium specimens are known from the period between 1846 and 1956 (Appendix 1). In total, 63 specimens including duplicates are deposited in the revised herbaria from 47 different collections (BP: 43, DE: 18, KBM: 1, GK: 1). The spatial distribution of the herbarium data reflects the collecting activities of the botanists. Most data originate from the periods 1920-1929 (14 sheets) and 1950-59 (13 sheets). The Hungarian distribution of S. pungens is shown in Fig. 3.

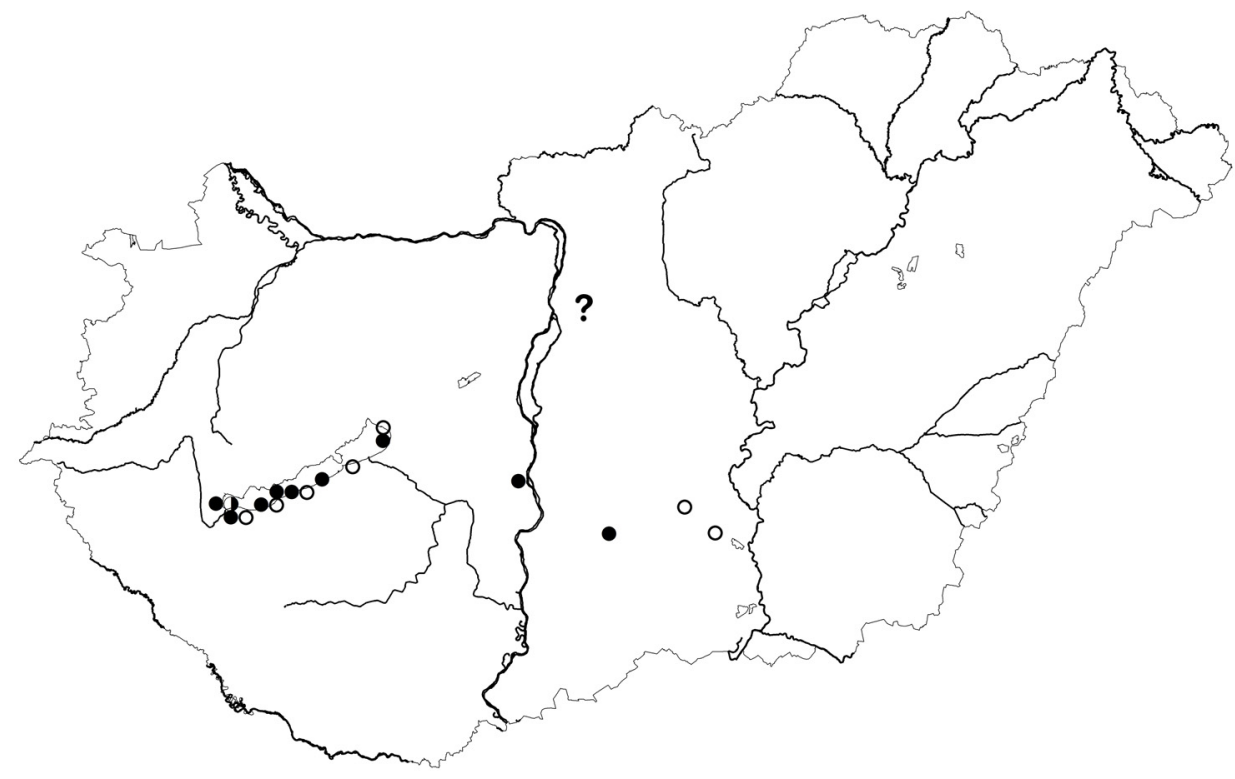

Fig. 3. Hungarian distribution of Schoenoplectus pungens (empty circles = occurrence before 1950; half-filled circles = occurrence between 1951 and 1990; full circles = occurrence after 1990) 


\section{Danube valley}

It was once collected in Rákos (1846, leg. Gy. Kováts). It is possible that suitable habitats occurred on the Rákos meadows at that time, but even if the species could be found there, it presumably disappeared by the beginning of the 20th century (DEGEN 1914).

MENYHÁRTH (1877) recorded it at Dunaföldvár, 'in sandy swamps - near Földvár in Fölsőtó, under the name Scirpus rothii. After that, there are no known observations until 2004, when it was found near Előszállás, not far from Felső-tó, in the planned route of the M6 motorway (9179.3, S. Farkas pers. comm.). This population has likely been destroyed due to the construction of the motorway, but the species may still exist elsewhere in the area.

\section{Danube-Tisza Interfluve}

Three of the herbarium specimens were collected in the vicinity of the salt lakes in the Danube-Tisza Interfluve (see Appendix 1). Despite Polgár's correctly determined specimen, the species is missing from the local floristic works (e.g. SzujKó-LaCza \& Kováts 1993).

Actual location: Soltvadkert, Vadkerti-tó - A small population on disturbed, trampled habitat on a beach, at the margin of the lake (9382.3, 2004, R. Vidéki).

\section{Small Hungarian Plain}

It was once collected at Tata, the exact site is not possible to localize (1890, leg. G. Perlaky). The correctness of this record is, however, questionable, because the species has later never been observed, and there are no suitable habitats in the area.

Soó (1973) mentions it at Lake Fertő, but we could not trace the origin of this record. No herbarium specimen was found from the Hungarian side of the lake. One sheet was found from the Austrian side (Illmitz, ad limites lacus salsi “Zick See", 24.06.1923, leg. J. Scheffer, BP). In Austria the closest site of the species lies at Apetlon where it is still present, only a few kilometres from the Hungarian border. It is possible that the Austrian locations were placed among the Hungarian occurrences by mistake.

\section{The coast of Lake Balaton}

Occurrence of $S$. pungens along the southern coast of Lake Balaton was first published by BORBÁs (1900), who characterized S. pungens as a typical element on the salty and wet sandy soil of the shore where reed (Phragmites australis) is lacking. He found that it was a frequent species on the southern coast and also occurred on the northern coast (at Keszthely, Badacsony, and Balatonkenese). Boros (1927, 
1936) provided several localities near Balatonkeresztúr, between Fonyód and Balatonboglár, at Balatonszárszó and one from the western coast at Fenékpuszta. The only observation of $S$. pungens in the last half of the 20th century was published by LÁJER (1998b), who discovered it in the mires of Nagyberek, near Balatonkeresztúr, but he could not find the species again subsequently (LÁJER 2007).

Between 1873 and 1956 it was regularly collected on the shores of Lake Balaton, 40 herbarium specimens originating from this area, representing $85 \%$ of all known sheets.

\section{Actual locations:}

1. Keszthely, Fenékpuszta - A smaller patch with Schoenus nigricans surrounded by shrubs of Salix cinerea, in the area north from the railway crossing (9269.3, 2004, R. Vidéki). In 2017 the habitat was dried out, overgrown by shrubs, and the species disappeared.

2. Balatonszentgyörgy - A grazed meadow at the edge of Kis-Balaton (9369.2, 2002, R. Vidéki). This location was revisited in 2018 and found overgrown by reed and tall sedges. The species has presumably disappeared from here.

3. Balatonmáriafürdő - A large population in mowed lawns and ditches in front of summer houses in Hullám street (9270.4, 2005, A. Mesterházy; revisited in 2018).

4. Fonyód - In shallow water at the lake margin, at the mouth of the Pogányvölgyi-víz (9271.1, 2017, M. Wolf).

5. Fonyód, Fonyódliget - A large population in a small park next to the lake, enclosed by newly built villas $(9271.1,2018, \mathrm{M}$. Wolf $)$.

6. Fonyód, Fonyódliget - On the beach, on heavily trampled, open surface next to the concrete pavement along the water (9271.2, 2018, M. Wolf).

7. Fonyód, Fonyódliget - A few individuals on open, sandy surface on the edge of a former mine pit (9271.2, 2013, A. Mesterházy). The site was revisited in 2018, but the species could not be found again.

8. Balatonszemes - On both sides of the eastern pier of the port, in shallow water and on wet sand on the shore $(9172.4,2018$, M. Wolf \& D. Schmidt).

9. Balatonvilágos - On the shore south of Club Aliga holiday resort, among deposited concrete and stone blocks (9074.2, 2013, D. Schmidt \& V. Tiborcz).

\section{Tapolca Basin}

Two herbarium specimens were found from Billegepuszta near Lesenceistvánd (see Appendix 1). The habitat characteristics of the fen meadows in the area significantly differ from the habitat requirements of the species. A great number of phytosociological relevés were recorded at Lesenceistvánd by Kovács 
(1962), who had the most thorough knowledge about this area; S. pungens was not included in any of these lists. On the label of the specimen collected by Boros, the name Eriophorum was written originally, and this genus indeed occurred at Lesenceistvánd. On these two herbarium sheets individuals of $S$. pungens are found, but we think that a mix-up of labels is likely in both cases.

\section{Dráva valley}

Along the Dráva river it was first recorded between Örtilos and Zákány (Kovács \& Priszter 1957). The species was later observed by LÁJER (1998a) at Zákány, on the island of the Dráva. However, there is no herbarium specimen confirming this record, and based on the habitat we suppose that poorly developed individuals of $S$. triqueter may have been misidentified as $S$. pungens. During our field studies only $S$. triqueter was found on the shoals of the Dráva at Zákány (and also on shoals in other reaches of the river).

\section{DISCUSSION}

S. pungens is a halophytic plant which may occur in a wide range of wet habitats. In Hungary there is only scarce information about its coenological features. It is a typical species of Schoenoplecto-Juncetum maritimi Soó (1930) 1971, which is a very rare association in Hungary occurring only along the southern coast of Lake Balaton (BORHIDi et al. 2012). To our knowledge there is no actual location of the species in this community. Our studies confirm that $S$. pungens is not bound to specific habitats or plant communities.

In two locations it was found in shallow water, on the margin of Lake Balaton, where it may form rather dense cover, or occurs scattered along the coastline with Schoenoplectus lacustris, Bolboschoenus maritimus s.l. and Phragmites australis. Along the shore of Lake Balaton the species was surprisingly discovered in a number of different disturbed habitats, e.g. frequently visited beaches, regularly mowed lawns, and ditches in front of summer houses. It seems to tolerate intensive mowing and trampling, but under such circumstances mostly small, vegetative individuals develop. Interestingly, remarkable populations of other rare or declining species, namely Samolus valerandi, Cyperus flavescens, and Hydrocotyle vulgaris were found at some of these locations (Balatonmáriafürdö, Fonyódliget), together with or in the vicinity of the studied species. At one site, in a small park by the lake in Fonyódliget, S. pungens grows in abundance on desiccated, saline soil, in open vegetation, accompanied by Plantago maritima and Aster tripolium. Farther from the lake, in the wetlands of Nagyberek and at the edge of Kis- 
Balaton, it appeared in places with significant disturbance, due to sand mining and grazing, respectively, and seemed to disappear after the disturbance ceased.

At its only actual site in the Danube-Tisza Interfluve $S$. pungens occurs in disturbed, trampled habitats at the margins of a lake, similarly to some sites on the Balaton shore.

Our observations show that disturbance is a common feature in the actual locations of $S$. pungens and, furthermore, it seems to be necessary for the longtime survival of the species on the remains of its former habitats.

The main cause of its decline is apparently habitat loss due to human activity. The remaining populations are located predominantly in settlements visited by a great number of tourists every year, in man-made habitats under the continuous threat of habitat destruction. It tolerates trampling and mowing but not the turning up or removing of the soil. In the former sand spits at the southern coast of Lake Balaton, where most of its historical locations were found, extensive earthworks were carried out and settlements were built. Another threat in more natural habitats can be the spread of Phragmites and other tall herbs, like Carex riparia or C. acutiformis.

In the light of the newly found populations, the shore of Lake Balaton represents an important site for $S$. pungens, not only at national level, but even in whole Central Europe, and legal protection of this rare and declining species should be considered. It is classified as 'least concern' on the European Red List of Vascular Plants (BILz et al. 2011), although it is scattered and nowhere frequent in its European distribution range. It should be noted, however, that its residence status in Europe is unclear. In some of the Western European countries, such as in France (TisON \& DE FoucAulT 2014) and in Belgium (Filip Verloove pers. comm.), S. pungens is considered to be a naturalized alien of North American origin, where it is a common and abundant plant in freshwater and brackish coastal wetlands (LARSON 1993, BALL et al. 2002). This could explain why only part of the morphological variability of the species is present in Europe. The supposed introduction could have happened a long time ago, because the species has long been known in the European flora. This theory could be verified by means of population genetics, but to our knowledge no such studies are going on at present.

In Central Europe $S$. pungens is a good indicator of threatened salty and wet sandy habitats, and therefore it is treated as an endangered species in several countries. The fact that we found it in disturbed, anthropogenic habitats only means that it tolerates disturbance well, and may survive the destruction of the habitat. We can also suppose that on the southern coast of Lake Balaton and in its former locations there could have been open patches in the potential vegetation in the past, where $S$. pungens could have occurred for a long time. Therefore, even 
if it is a long-naturalized alien, it deserves protection as a remaining indicator species of these habitats.

This paper would also like to draw attention to the importance of further study of the flora of the coast of Lake Balaton. The surroundings of the lake have changed dramatically in the last one and a half century, since the Sió channel was opened in 1863 and, with the drainage of the water and the regulation of the water level, the lake gained its present-day form. As BORBÁs (1900) predicted, the southern coast has changed to an almost continuous settled area, and is today made up of residential and recreational areas, beaches and ship ports, roads and railway infrastructure. In the second half of the twentieth century the lake became a very popular tourist destination, and at present it attracts millions of tourists every summer.

Populations of $S$. pungens may have remained undiscovered for such a long time because the southern coast became unattractive to botanists, and the field studies carried out there in the last half a century were not focusing on the vegetation of the inhabited areas. Another reason why it was probably overlooked can be that intensively mowed, trampled, scarcely flowering populations are very inconspicuous and difficult to spot. Although it can flower and produce ripe fruits in these places, it also spreads vegetatively, which can be facilitated by the continuous mowing. We presume that further populations of $S$. pungens exist in Hungary, mostly on the southern shore of Lake Balaton, where it may hide in private properties that are hardly accessible for botanists.

Acknowledgements - The authors would like to thank Rolf Rutishauser (University of Zurich, Switzerland), Filip Verloove (Botanic Garden Meise, Belgium), and Antoine Gazaix (Tour du Valat, France) for their help with collecting data on the European distribution of the species. We would also like to thank Judit Bódis, Attila Takács, and Zoltán Barina for their help with the herbarium work, and Zoltán Bajor for valuable information about the historical and actual vegetation of the Rákos meadows. We are grateful to Sándor Farkas for sharing his unpublished data. The illustrations and the photographs were made by Jane Browning (Royal Botanic Gardens, Kew). Filip Verloove kindly improved the English of the manuscript and provided useful comments.

Összefoglaló: A vékony káka (Schoenoplectus pungens) a magyar flóra kevéssé ismert tagja, melynek hazai elterjedéséről és élőhelyi viszonyairól alig rendelkezünk aktuális ismeretekkel. A növényt az utóbbi években számos helyen megtaláltuk, elsősorban zavart, antropogén élőhelyeken a Balaton déli partja mentén. Jelen közleményben részletesen áttekintjük a faj hazai irodalmi adatait, előfordulásait a főbb magyarországi herbáriumok gyüjteményében, valamint ismertetjük az újonnan felfedezett állományok élőhelyi viszonyait. Megfogyatkozásának elsődleges okaként az élőhelyek pusztítása tehető felelőssé, mely főleg a turizmussal áll összefüggésben. Ennek ellenére számos helyen fennmaradt, többek között strandokon, árkokban, erösen taposott és fünyírózott gyepekben, ahol valószínűleg vegetatívan is terjeszkedik. Ezeken az élőhelyeken a növény 
könnyen észrevétlen maradhatott az elmúlt évtizedekben, részben mivel kis termetü, alig virágzó példányok fejlödnek, részben mivel a florisztikai kutatások során a lakott területek vegetációjának feltárására kevés figyelem fordulhatott. Munkánkban szeretnénk hangsúlyozni, hogy a Balaton déli partjának flórája további kutatásokat igényel, és a beépített területek látszólag értéktelen élőhelyein a $S$. pungens és több más, országosan ritka vagy fogyatkozó növény újabb állományai kerülhetnek elö.

\section{REFERENCES}

Ball P. W., Reznicek A. A. \& Murray D. A. (2002): Cyperaceae. - In: Flora of North America Editorial Committee (ed.) (1993+). Flora of North America North of Mexico. 20+ vols., Oxford University Press, New York.

Bañares Á., Blanca G., Güemes J., Moreno J. C. \& Ortiz S. (eds) (2004): Atlas y libro rojo de la flora vascular amenazada España. - Dirección General de Conservación de la Naturaleza, Madrid, 1069 pp.

Bartha D., Király G., Schmidt D., Tiborcz V., Barina Z., Csiky J., Jakab G., Lesku B., Schmotzer A., Vidéki R., Vojt kó A. \& Zólyomi Sz. (eds) (2015): Distribution atlas of vascular plants of Hungary. - University of West Hungary Press, Sopron, 329 pp.

Bilz M., Kell S. P., MAXTED N. \& LANsDown R. V. (2011): European red list of vascular plants. Publications Office of the European Union, Luxembourg, $130 \mathrm{pp}$.

BorBÁs V. (1900): A Balaton tavának és partmellékének növényföldrajza és edényes növényzete. - A Balaton tudományos tanulmányozásának eredményei. M. Földr. Társ. Balaton-Biz., Budapest, II. 2, $431 \mathrm{pp}$.

Borhidi A., Kevey B. \& Lendvai G. (2012): Plant communities of Hungary. - Akadémia Kiadó, Budapest, $544 \mathrm{pp}$.

Bornand C., Gygax A., Juillerat P., Jutzi M., Möhl A., Rometsch S., Sager L., Santiago H. \& Eg Genberg S. (2016): Rote Liste Gefässpflanzen. Gefäbrdete Arten der Schweiz. - Bundesamt für Umwelt, Bern und Info Flora, Genf. Umwelt-Vollzug Nr. 1621, 178 pp.

Boros Á. (1927): A Balaton vizének és partjának néhány növényéről. - Az MTA Tihanyi Biológiai Kutatóintézetének évkönyve. Archivum Balatonicum 1: 178-180.

Boros Á. (1936): Adatok Somogy vármegye flórájának ismeretéhez. - Folia Sabariensa - Vasi Szemle 3: 79-86.

Danihelka J., Chrtek J. Jr. \& Kaplan Z. (2012): Checklist of vascular plants of the Czech Republic. - Preslia 84: 647-811.

DANYly I. M. \& HonChaRen Ko V. I. (2009): Schoenoplectus pungens (Vahl) Palla (Cyperaceae), a new species for of the Ukrainian flora. - Ukr. Bot. Zhurnal 66: 650-655.

DeFilipps R. A. (1980): Scirpus L. - In: Tutin T. G., Heywood V. H., Burges D. M., Valentine D. H., Walters S. M. \& Webb D. A. (eds): Flora Europaea. Vol. 5. Alismataceae to Orchidaceae (Monocotyledones). Cambridge University Press, Cambridge, pp. 277-280.

DEgEN Á. (1914): Szandovics Rudolf: A Rákosvidék flórájának főbb jellemvonásai. (Hazai botanikai dolgozatok ismertetése.) - Magyar Bot. Lapok 13: 154-155.

Fischer M. A., Adler W. \& Oswald K. (2008): Exkursionsflora für Österreich, Liechtenstein und Südtirol. - Land Oberösterreich, OÖ Landesmuseen, Linz, 1392 pp.

Gilli C. \& NikLfeld H. (2018): Floristische Neufunde (236-304). - Neilreichia 9: 289-354.

Govaerts R., Simpson D. A., Bruhl J. J., Egorova T., Goetghebeur P. \& Wilson K. L. (2007): World checklist of Cyperaceae. Sedges. - Royal Botanic Gardens, Kew, 765 pp.

HAeupler H. \& Muer T. (2007): Bildatlas der Farn- und Blütenpflanzen Deutschlands. - 2. Aufl., Eugen Ulmer Verlag, Stuttgart, 789 pp. 
Kaźmierczakowa R., Bloch-Oreowska J., Celka Z., Cwener A., Dajdok Z., MichalskaHejduk D., PAwlikows ki P., SzczęŚniak E. \& Ziarnek K. (2016): Polska czerwona lista paprotników $i$ roślin kwiatowych. (Polish red list of pteridophytes and flowering plants). Instytut Ochrony Przyrody Polskiej Akademii Nauk, Kraków, 44 pp.

Király G. (ed.) (2007): Vörös Lista. A magyarországi edényes flóra veszélyeztetett fajai. (Red list of the vascular flora of Hungary). - private edition, Sopron, $73 \mathrm{pp}$.

KIRÁly G. (ed.) (2009): Új magyar füvészkönyv. Magyarország hajtásos növényei. Határozókulcsok. (New Hungarian herbal. The vascular plants of Hungary. Identification key). - Aggteleki Nemzeti Park Igazgatóság, Jósvafö, 616 pp.

Király G., Virók V. \& Molnár V. A. (eds) (2011): Új magyar füvészkönyv. Magyarország hajtásos növényei. Ábrák. (New Hungarian herbal. The vascular plants of Hungary. Illustrations). Aggteleki Nemzeti Park Igazgatóság, Jósvafő, 676 pp.

KovÁcs M. \& Priszter Sz. (1957): Kiegészítések és adatok “A magyar növényvilág kézikönyvé”hez. - Bot. Közlem. 47: 87-93.

Kovács M. (1962): Die Moorwiesen Ungarns. - Akadémiai Kiadó, Budapest, 213 pp.

LÁJER K. (1998a): Az Aldrovanda vesiculosa L. újabb előfordulása és egyéb adatok Magyarország flórájának ismeretéhez. - Kitaibelia 3(2): 263-274.

LÁJER K. (1998b): Újabb adatok Belső-Somogy flórájának és vegetációjának ismeretéhez. - Somogyi Múz. Közlem. 13: 217-239.

LÁjER K. (2007): A Nagyberek flórájának és lápi-mocsári vegetációjának alapvonásai. - Natura Somogyiensis 10: 73-93.

LARSON G. E. (1993): Aquatic and wetland vascular plants of the northern Great Plains. - Gen. Tech. Rep. RM-GTR-238. Fort Collins, CO: U.S. Department of Agriculture, Forest Service, Rocky Mountain Forest and Range Experiment Station, $681 \mathrm{pp}$.

Luceño M. \& Jiménez Mejías P. (2007): Schoenoplectus (Rchb.) Palla [nom. cons]. - In: Castroviejo S., Luceño M., Galán A., Jiménez Mejías P., Cabezas F. \& Medina L. (eds): Flora Iberica. Vol. 18. Cyperaceae-Pontederaceae. Real Jardín Botánico, CSIC, Madrid, pp. 42-59.

MenYhárth L. (1877): Kalocsa vidékének növénytenyészete. - Hunyadi Mátyás Intézet, Budapest, 198 pp.

Ni KLFELd H. (1971): Bericht über die Kartierung der Flora Mitteleuropas. - Taxon 20(4): 545-571. https://doi.org/10.2307/1218258

Pignotti L. (2003): Scirpus L. and related genera (Cyperaceae) in Italy. - Webbia 58(2): 281-400.

Pires M. \& Pavon D. (eds) (2018): La Flore remarquable des Bouches-du-Rhône. Plantes, milieux naturels et paysages. - Biotope éditions, Mèze, $468 \mathrm{pp}$.

Preston C. D., Pearman D. A. \& Dines T. D. (eds) (2002): New atlas of the British and Irish flora. - University Press, Oxford, 910 pp.

Soó R. (1973): A magyar flóra és vegetáció rendszertani-növényföldrajzi kézikönyve V. (Synopsis systematico-geobotanica Florae Vegetationisque Hungariae V). - Akadémiai Kiadó, Budapest, 724 pp.

STACE C. (2010): New flora of the British Isles. - 3rd edition, Cambridge University Press, Cambridge, $1232 \mathrm{pp}$.

Szuj Kó-Lacza J. \& Kováts D. (eds) (1993): The Flora of the Kiskunság National Park in the DanubeTisza Mid-Region of Hungary. Vol. 1. The Flowering Plants. - Magyar Természettudományi Múzeum, Budapest, $469 \mathrm{pp}$.

Tison J.-M. \& De Foucault (eds.) (2014): Flora Gallica. Flore de France. Biotope, Mèze, 1196 pp.

VAN Landuyt W., Hoste I., Vanhecke L., VAN den Bremt P., Vercruysse W. \& De Beer D. (2006): Atlas van de Flora van Vlaanderen en het Brussels Gewest. - Instituut voor Natuur- en Bosonderzoek, Nationale Plantentuin van België \& Flo. Wer., 1007 pp.

(submitted: 12.04.2019, accepted: 06.05.2019) 


\section{Appendix 1. List of the collected specimens of Schoenoplectus pungens in the revised Hungarian herbaria.}

1. Rákos (most likely 8480.4 or 8581 .1, the exact site is not possible to localize); leg.: Gy. Kováts, 04.06.1846, BP.

2. Ad litus locus Balaton prope urbem Keszthely (9269.1 or 9269.2 or 9269.3); leg.: L. Simkovics, 16.08.1873, BP.

3. Ad lacum Balaton prope Keszthely (9269.1 or 9269.2 or 9269.3); leg.: L. Simkovics, 16.08.1873, BP.

4. In ripa lacus Balaton prope oppidium Keszthely (9269.1 or 9269.2 or 9269.3); leg.: L. Simkovics, 16.08.1873, BP.

5. In arenosis ad marginem lacus Balaton prope pagum Boglár [= Balatonboglár] (9271.2); leg.: L. Simkovics, 19.08.1873, BP.

6. In arundinetis locus majoris ad opp. Tata (8375.2 or 8375.4 or 8376.1 or 8376.3 ); leg.: G. Perlaky, 20.07.1890, BP; originally determined as $S$. maritimus, revised by E. Jablonszky.

7. In campis ad Siófok (9074.3 or 9074.4$)$; leg.: V. Borbás, 08.1893, BP; originally determined as S. mucronatus.

8. In litore salso lacus ad pagum Kenese [= Balatonkenese] (8974.4); leg.: L. Simonkai, 04.10.1903, BP.

9. Balaton partja Kenesénél [= Balatonkenese] (8974.4); leg.: S. Jávorka, 04.10.1903, BP.

10. A Balaton parti mocsaraiban Faluszemes [= Balatonszemes] mellett. Agyagtalajon. (9172.4); leg.: A. Paikert, 06.08.1910, BP, GK.

11. Ad ripam lacus Balaton prope Boglár [= Balatonboglár] (9271.2); leg.: S. Polgár, 08.14.1911, BP, DE.

12. In paludosis praedii Páka ad Félegyháza [= Kiskunfélegyháza] (9284.4); leg.: G. Lengyel, 01.08.1926, BP; originally determined as S. triqueter, revised by A. Mesterházy 13.02.2008.

13. In paludosis ripae lacus Balaton ad Zamárdi (9173.2); leg.: Á. Boros, 07.08.1926, BP.

14. In locus paludosis ripae lacus Balaton ad Balatonkeresztúr (9270.3); leg.: Á. Boros, 07.08.1926, BP.

15. In pratis ad Pálmonostora (9385.4); leg.: G. Lengyel, 23.08.1926, BP; originally determined as S. triqueter, revised by A. Mesterházy 13.02.2008.

16. In arenosis humidis ripae lacus Balaton ad Fenékpuszta prope Keszthely, Á. Boros, 21.06.1927, (9269.3 or 9269.4$)$, BP.

17. In arenosis humidis ripae lacus Balaton ad Balatonboglár, (9271.2); leg.: Á. Boros, 22.06.1927, BP.

18. In arenosis humidis ripae lacus Balaton ad Balatonszemes (9172.4); leg.: Á. Boros, 22.06.1927, BP, DE.

19. In arenosis humidis ripae lacus Balaton ad Fonyód (9271.1 or 9271.3); leg.: Á. Boros, 22.06.1927, BP.

20. In arenosis humidis ripae lacus Balaton ad Balatonszárszó (9172.4 or 9173.3); leg.: Á. Boros, 22.06.1927, BP.

21. Ad ripam lacus natronati apud Soltvadkert (9382.3); leg.: S. Polgár, 03.07.1927, BP.

22. Tapolca, in limosis rivuli ad Billege csárda versus Lesenceistvánd, unicum Pinguicula alpina (9170.1); leg.: S. Jávorka, 26.06.1927, BP.

23. Ad ripam lacus Balaton prope Siófok (9074.3 or 9074.4), leg.: S. Polgár, 03.09.1927, DE.

24. Siófok, in arenosis humidis pr. pagum Siófok (9074.3 or 9074.4); leg.: R. Soó, 29.05.1928, KBM.

25. In arenosis ad ripam lacum Balaton prope Balaton-Berény [= Balatonberény] (9269.4); leg.: L. Papp, 05.08.1928, BP. 
26. In limosis ripae lacus Balaton ad pag. Balatonzamárdi [= Zamárdi] (9173.2); leg.: S. Jávorka, 15.07.1930, BP, DE.

27. Siófok, L. Vajda (9074.3 or 9074.4); 04.10.1931, BP.

28. In arenosis humidis ripae lacus Balaton prope Fonyód (9271.1 or 9271.3); leg.: Á. Boros, 16.09.1933, BP.

29. Balatonlelle, a parti iszapban Szemes felé (9272.1); leg.: S. Jávorka, 09.1944, BP.

30. Balatonlelle, a parti iszapban Szemes alatt bőven (9272.1); leg.: S. Jávorka, 09.1944, BP.

31. Balaton partján nedves réten, Keszthely mellett (9269.1 or 9269.2 or 9269.3 ); leg.: L. Bánó, 23.08.1944, BP.

32. In arenosis humidis pr. Pag. Fonyódszéplak [= Fonyód] (9271.3); leg.: Á. Károlyi, 24.06.1946, BP.

33. In arenosis humidis pr. pagum Öszöd ad ripas lacus Balaton [= Balatonőszöd] (9172.4), leg.: Á. Károlyi, 04.09.1949, BP, DE.

34. Keszthely, Balaton-part (9269.1 or 9269.2 or 9269.3 ); leg.: V. Csapody, 23.08.1949, BP.

35. In turfosis Sörény ad Billege-puszta prope Lesenceistvánd (9170.1); leg.: Á. Boros, 04.06.1950, BP; revised by L. Felföldy.

36. In arenosis humidis ad ripae lacus Balaton prope pagum Balatonszemes (9172.4); leg.: L. Bánó, 09.09.1951, BP.

37. Balatonszemes mellett, nedves rét (9172.4); L. Bánó, 14.09.1951, BP.

38. Secus vias pr.pag. Balatonmária [= Balatonmáriafürdő] (9270.3 or 9270.4); leg.: Á. Károlyi, 21.06.1953, BP.

39. Balatonföldvár, nedves rét (9173.1 or 9173.3); leg.: L. Bánó, 07.07.1953, BP.

40. Keszthely, Balatonpart (9269.1 or 9269.2 or 9269.3 ); leg.: Z. Siroki, 06.07.1955, DE.

41. Keszthely, Balatonpart. Nádas szélén (9269.1 or 9269.2 or 9269.3 ); leg.: Z. Siroki, 06.07.1955, DE.

42. Keszthely, Balatonparton (9269.1 or 9269.2 or 9269.3 ); leg.: Z. Siroki, 14.07.1955, DE.

43. Fenékpuszta, a Balaton partján (9269.3 or 9269.4); leg.: Z. Siroki, 29.07.1955, DE.

44. Keszthely, Balatonpart (9269.1 or 9269.2 or 9269.3 ); leg.: Z. Siroki, 03.08.1955, DE.

45. Ad ripas lac. Balaton dit. pr. pag. Balatonberény (9269.4); leg.: Á. Károlyi, 08.10.1956, BP.

46. Ad ripas lac. Balaton dit. pr. pag. Balatonboglár (9271.2); leg.: Á. Károlyi, 08.10.1956, BP.

47. Ad ripas lac. Balaton pr. opp. Balatonboglár (9271.2); leg.: Á. Károlyi, 22.07.1956, BP. 